Bioedusiana

Volume 01, Nomor 01, September 2016

ISSN 2477-5193

\title{
PERBEDAAN KEAKTIFAN BELAJAR DAN HASIL BELAJAR KOGNITIF PLH PADA KONSEP ETIKA LINGKUNGAN DENGAN MENGGUNAKAN MODEL PEMBELAJARAN KOOPERATIF TIPE NUMBERED HEADS TOGETHER (NHT) DAN TIPE TEAMS GAME TOURNAMENT(TGT).
}

\author{
Popo Musthofa Kamil ${ }^{1}$ \\ 1,2 Jurusan Pedidikan Biologi, FKIP, Universitas Siliwangi \\ Jl. Siliwangi Tasikmalaya.
}

\begin{abstract}
ABSTRAK : Penelitian ini bertujuan untuk (1) mengetahui perbedaan keaktifan belajar siswa anatara model pembelajaran kooperatif Tipe Numbered Heads Together (NHT) dengan model pembelajaran kooperatif tipe Teams Game Tournament (TGT). (2) mengetahui perbedaan hasil belajar kognitif siswa anatara model pembelajaran kooperatif Tipe Numbered Heads Together (NHT) dengan model pembelajaran kooperatif tipe Teams Game Tournament (TGT). Penelitian ini menggunakan metode quasi eksperiment. Desain penelitian adalah post test group desaind. Berdasarkan hasil penelitian, (1) terdapat perbedaan keaktifan belajar siswa antara yang menggunakan model pembelajaran kooperatif tipe Numbered Heads Together (NHT) yang di terapkan di kelas X-2 dan model pembelajaran kooperatif tipe Teams Game Tournament (TGT) yang di terapkan di kelas X-6 pada konsep Etika Lingkungan. Hal ini berdasarkan hasil observasi yang menunjukan bahwa skor rata-rata kelas X-2 memperoleh rata-rata 11,74 yang lebih baik dibandingkan kelas X-6 yang memperoleh rata-rata 11,64. (2)terdapat perbedaan hasil belajar kognitif siswa antara yang menggunakan model pembelajaran kooperatif tipe Numbered Heads Together (NHT) yang di terapkan di kelas X-2 dan model pembelajaran kooperatif tipe Teams Game Tournament (TGT) yang di terapkan di kelas X-6 pada konsep Etika Lingkungan. Hal ini berdasarkan hasil tes kognitif yang menunjukan bahwa skor rata-rata kelas X-2 memperoleh ratarata 24,88 yang lebih baik dibandingkan kelas X-6 yang memperoleh rata-rata 22,98.
\end{abstract}

Kata Kunci : model pembelajaran kooperatif numbered heads together, teams game tournament, hasil belajar kognitif, keaktifan belajar.

ABSTRACT : This study attempts to (1) knows the difference liveliness student learning state of the cooperative learning model type numbered heads \& together (NHT) with model cooperative learning type teams game tournament (TGT). (2) know the difference of the results learn cognitive students state of the learning model cooperative type numbered heads \& together (NHT) with model cooperative learning type teams game tournament (TGT). This research uses the method quasi eksperiment. Design research is post test group desaind. Based on the research done, (1) there is a difference liveliness student learning between use the model cooperative learning type numbered heads \& together (NHT) apply in the class X-2 and model cooperative learning type teams game tournament (TGT) apply in the class $x-6$ the concept ethics environment. It is based on the results of observation which showed that the average score class $x$-2 obtain the average 11,74 more better than class $x-6$ received an average of 22,98 .

Keywords:cooperative learning model numbered heads \& together, teams game tournament, results cognitive study, liveliness learning 


\section{PENDAHULUAN}

Model pembelajaran yang
dipandang lebih tepat untuk
meningkatkan aktivitas siswa dalam
belajar adalah model pembelajaran
yang dapat merangsang siswa untuk
lebih aktif terlibat langsung dalam
proses belajar-mengajar dan
memberikan kesempatan kepada
siswa untuk mengemukakan
pendapatnya dalam proses belajar
mengajar sehingga terjalin interaksi
yang dinamis antara guru dengan
siswa dan interaksi antara siswa itu
sendiri. Salah satu model
pembelajaran yang bisa digunakan
adalah model pembelajaran
kooperatif.
Model andajaran kooperatif memberikan kebebasan kepada siswa untuk bisa belajar lebih aktif, sehingga dari keadaan tersebut dapat tercipta suatu interaksi yang baik, namun model pembelajaran ini guru bukan satu-satunya sumber informasi bagi siswa. Model Cooperative Learning memiliki beberapa tipe diantaranya Jigsaw, Group Investigation (GI), Make a Match, Student Team Achievement Division (STAD), Teams Game Tournament (TGT), Cooperative Integrated Reading and Composition (CIRC), Numbered Head Together (NHT), dan lain-lain.

Menurut Sardiman (2001: 98)

"Aktifitas belajar adalah kegiatan yang bersifat fisik maupun mental, yaitu berbuat dan berfikir sebagai suatu rangkaian yang tidak dapat dipisahkan"

Menurut Slameto (2003: 2)

"Belajar ialah suatu proses usaha yang dilakukan seseorang untuk memperoleh suatu perubahan tingkah laku yang baru secara keseluruhan, sebagai hasil pengalamannya sendiri dalam interaksi dengan lingkungannya"

Menurut Hamalik, Oemar (2009 : 48) menyatakan, "mengajar adalah usaha mengorganisasikan lingkungan sehingga menciptakan kondisi belajar bagi siswa".

Model Kooperatif tipe Numbered Head Together (NHT) dikembangkan oleh Spencer Kagan pada tahun 1992. Model kooperatif tipe Numbered Head Together (NHT) merupakan suatu model belajar dimana setiap siswa diberi nomor kemudian dibuat suatu kelompok, kemudian secara acak guru memanggil nomor siswa.

Model koperatif TGT dikembangkan oleh E. Slavin pada tahun 1990. Model TGT adalah pembelajaran kooperatif yang ditambah dengan suatu kegiatan yaitu turnament akademik

Berdasarkan hasil wawancara dengan siswa dan guru PLH di SMA Negeri 5 Tasikmalaya, kelas $\mathrm{X}$ merupakan kelas yang siswanya memiliki kemampuan yang beragam. Tetapi sebagian siswa di kelas tersebut masih kurang dalam memahami materi pelajaran PLH pada konsep Etika Lingkungan. Hal ini menunjukkan kurangnya kemampuan pemahaman siswa dalam pembelajaran PLH, sehingga siswa tidak mampu memecahkan dan menyelesaikan soal-soal yang diberikan. Dalam proses pembelajarannya guru menerapkan metode ceramah dimana informasi yang diperoleh semata-mata hanya didapat dari guru. Metode ceramah sangat tidak tepat digunakan dalam pembelajaran PLH, karena PLH bukan materi yang harus diceritakan 
melainkan suatu materi yang memerlukan aktivitas siswa untuk memahami konsep-konsep. Sehingga hal inilah yang menyebabkan hasil belajar yang kurang optimal dan kurangnya minat siswa dalam pembelajaran.

\section{Metode Penelitian}

Penelitian ini dilaksanakan dengan menggunakan metode quasi eksperiment, karena bermaksud mengetahui hubungan sebab akibat dua variabel atau lebih.

\section{Variabel Penelitian}

Variabel dalam penelitian ini dibagi dua variabel yaitu variabel bebas dan variabel terikat. Ada 2 variabel bebas $(\mathrm{X})$ dalam penelitian ini yaitu X1 dan X2. Model pembelajaran kooperatif tipe Numbered Heads Together (X1) dan Model pembelajaran kooperatif tipe Teams Game Tournament (X2). Sedangkan variabel terikatnya (Y), terdiri dari dua variabel yaitu $\mathrm{Y} 1$ dan Y2, keaktifan belajar siswa (Y1), hasil belajar kognitif siswa (Y2).

\section{Teknik Pengumpulan Data}

Teknik pengumpulan data untuk mengukur keaktifan belajar siswa dalam penelitian ini adalah dengan menggunakan lembar observasi. Besar keaktifan belajar siswa adalah jumlah nilai yang diperoleh siswa pada lembar observer. Sedangkan untuk mengetahui hasil belajar kognitif siswa digunakan teknik tes.

\section{Instrumen Penelitian}

Instrumen yang digunakan untuk mengetahui hasil belajar siswa adalah tes objektif berbentuk pilihan ganda dengan lima option sebanyak 40 soal. Tes yang diukur ranah kognitif yang dibatasi pada aspek mengingat $\left(\mathrm{C}_{1}\right)$, memahami $\left(\mathrm{C}_{2}\right)$, dan menerapkan $\left(\mathrm{C}_{3}\right)$.

\section{Teknik Analisis Data}

Langkah pertama penelitian ini menganalisa dan mengolah data untuk menguji Reliabilitas dan Validitas instrumen. Teknik analisa data yang dilakukan dengan cara uji t. Selain teknik-teknik analisa tesebut untuk kepentingan deskripsi data juga dilakukan perhitungan rata-rata (mean), skor terendah dan skor tertinggi serta simpangan baku

Sebelum uji hipotesis dilakukan terlebih dahulu di uji prasyaratan analisisnya yaitu uji normalitas dengan menggunakan uji chi kuadrat dan uji homogenitas varians. Semua pengujian dilakukan dengan taraf signifikan atau taraf $\alpha=$ 0,05

\section{Hasil Penelitian dan Pembahasan.}

\section{a. Keaktifan Belajar Siswa Dengan menggunakan Model Pembelajaran kooperatif tipe Numbered Heads Together (NHT)}

Untuk melihat keaktifan siswa kelas X-2 yang menggunakan tipe Numbered Heads Together (NHT), dilakukan dengan menggunakan teknik observasi, adapun yang dinilai terdiri dari 4 aspek yaitu aspek keseriusan siswa dalam proses pembelajaran, mengemukakan gagasan atau ide, melakukan bertanya atau menjawab pertanyaan dan disiplin siswa untuk lebih jelas hasil observasi mengenai keaktifan siswa kelas X-2 dapat dilihat pada tabel berikut ini.

\section{Data Statistik Hasil Observasi Keaktifan Siswa Kelas X-2}




\begin{tabular}{|c|c|c|c|c|c|}
\hline $\mathrm{N}$ & $\bar{X}$ & $\begin{array}{c}\text { Vari } \\
\text { an }\end{array}$ & Sd & $\begin{array}{c}\text { Skor } \\
\text { Min }\end{array}$ & $\begin{array}{c}\text { Skor } \\
\text { Mak }\end{array}$ \\
\hline 42 & $\begin{array}{c}11,7 \\
4\end{array}$ & 4 & 2 & 7 & 18 \\
\hline \multicolumn{7}{|c|}{ Untuk nendeskripsikan hasil }
\end{tabular}
observasi mengenai keaktifan siswa yang pembelajarannya menggunakan model pembelajaran kooperatif tipe Numbered Heads Together (kelas X2), maka ditentukan kriterianya sesuai dengan ketentuan berikut :

$$
\begin{aligned}
& 7+4(2)=15 \\
& 7+3(2)=13 \\
& 7+2(2)=11 \\
& 7+1(2)=9 \\
& \text { Dengan demikian kriteria }
\end{aligned}
$$
keaktifan siswa dapat dilihat pada tabel.

Tabel

\section{Kriteria keaktifan Siswa Kelas X-2}

\begin{tabular}{|c|c|c|c|}
\hline $\begin{array}{c}\text { Rentang } \\
\text { Skor }\end{array}$ & Harga & $\begin{array}{c}\text { Rentan } \\
\text { g Skor }\end{array}$ & Kategori \\
\hline $\begin{array}{c}\text { Skor Min + 4 } \\
\text { (Std Deviasi) }\end{array}$ & 15 & $\geq 15$ & $\begin{array}{c}\text { Sangat } \\
\text { baik }\end{array}$ \\
\hline $\begin{array}{c}\text { Skor Min + 3 } \\
\text { (Std Deviasi) }\end{array}$ & 13 & $\begin{array}{c}\geq 13 \\
<15\end{array}$ & Baik \\
\hline $\begin{array}{c}\text { Skor Min + 2 } \\
\text { (Std Deviasi) }\end{array}$ & 11 & $\begin{array}{c}\geq 11<1 \\
3\end{array}$ & Cukup \\
\hline $\begin{array}{c}\text { Skor Min + 1 } \\
\text { (Std Deviasi) }\end{array}$ & 9 & $\geq 9<11$ & Rendah \\
\hline & & $<9$ & $\begin{array}{c}\text { Sangat } \\
\text { Rendah }\end{array}$ \\
\hline
\end{tabular}

Sumber : hasil pengolahan data

Berdasarkan kriteria di atas, maka keaktifan siswa yang proses menggunakan model pembelajaran kooperatipe tipe Numbered Heads Together (NHT), dengan nilai ratarata sebesar 11,74 termasuk pada kategori cukup (11 - 13). Dengan demikian siswa yang proses pembelajaran menggunakan model pembelajaran kooperatif tipe Numbered Heads Together (NHT) yaitu kelas X-2 memiliki tingkat keaktifan yang cukup.

\section{b. Keaktifan Belajar Siswa Dengan Menggunakan Model Pembelajaran Kooperatif tipe Teams Game Tournament (TGT)}

Untuk melihat keaktifan siswa X-6 yang menggunakan model koopertipe tipe Teams Game Tournament dilakukan dengan menggunakan teknik observasi, adapun yang di nilai terdiri dari 4 aspek yaitu aspek keseriusan siswa dalam proses pembelajaran, mengemukakan gagasan dan disiplin siswa. Untuk lebih jelas hasil observasi mengenai keaktifan siswa kelas X-6 dapat di lihat pada tabel berikut.

\section{Data Statistik Hasil}

Observasi Keaktifan Siswa Kelas

\begin{tabular}{|c|c|c|c|c|c|}
\multicolumn{7}{|c}{ X-6 } \\
\hline N & $\bar{X}$ & $\begin{array}{c}\text { Vari } \\
\text { an }\end{array}$ & Sd & $\begin{array}{c}\text { Skor } \\
\text { Min }\end{array}$ & $\begin{array}{c}\text { Skor } \\
\text { Maks }\end{array}$ \\
\hline 42 & $\begin{array}{c}11, \\
64\end{array}$ & 7,5 & 2,7 & 6 & 19 \\
\hline
\end{tabular}

Untuk mendeskripsikan hasil observasi mengenai keaktifan siswa yang pembelajarannya menggunakan model pembelajaran kooperatif tipe Teams Game Tournament (kelas X6), maka ditentukan kriterianya sesuai dengan ketentuan sebagai berikut :

$$
\begin{aligned}
& 6+4(2,7)=17 \\
& 6+3(2,7)=14 \\
& 6+2(2,7)=11 \\
& 6+1(2,7)=9
\end{aligned}
$$$$
\text { Dengan demikian kriteria }
$$
keaktifan siswa dapat di lihat pada tabel berikut ini.

Tabel

Kriteria keaktifan Siswa Kelas X-6 


\begin{tabular}{|c|c|c|c|}
\hline $\begin{array}{l}\text { Rentang } \\
\text { Skor }\end{array}$ & Harga & $\begin{array}{c}\text { Rentang } \\
\text { Skor }\end{array}$ & $\begin{array}{c}\text { Katego } \\
\text { ri }\end{array}$ \\
\hline $\begin{array}{l}\text { Skor Min + } 4 \\
\text { (Std Deviasi) }\end{array}$ & 17 & $\geq 17$ & $\begin{array}{c}\text { Sangat } \\
\text { baik }\end{array}$ \\
\hline $\begin{array}{l}\text { Skor Min + } 3 \\
\text { (Std Deviasi) }\end{array}$ & 14 & $\geq 14<17$ & Baik \\
\hline $\begin{array}{l}\text { Skor Min + } 2 \\
\text { (Std Deviasi) }\end{array}$ & 11 & $\geq 11<14$ & Cukup \\
\hline \multirow[t]{2}{*}{$\begin{array}{l}\text { Skor Min + } 1 \\
\text { (Std Deviasi) }\end{array}$} & 9 & $\geq 9<11$ & Rendah \\
\hline & & $<9$ & $\begin{array}{l}\text { Sangat } \\
\text { Rendah }\end{array}$ \\
\hline
\end{tabular}

Sumber : hasil pengolahan data

Berdasarkan kriteria di atas, maka keaktifan siswa yang proses menggunakan model pembelajaran kooperatipe tipe Teams Game Tournament(TGT), dengan nilai rata-rata sebesar 11,64 termasuk pada kategori cukup (11 - 14). Dengan demikian siswa yang proses pembelajaran menggunakan model pembelajaran kooperatif tipe Teams Game Tournament(TGT) yaitu kelas X-6 memiliki tingkat keaktifan yang cukup.

c. Hasil Kognitif Siswa Dengan

Menggunakan Model

Pembelajaran Kooperatif tipe Numbered Heads Together (NHT)

Berdasarkan tes hasil belajar pada konsep Etika Lingkungan yang telah dilakukan terhadap siswa kelas X-2 SMA Negeri 5 Tasikmalaya, sebanyak 30 soal dengan rentang skor 0 sampai 30 diperoleh hasil sebagai berikut:
Data StatistikHasil Belajar Kognitif Siswa yang Menggunakan Model Pembelajaran Kooperatif Tipe Numbered Heads Together (NHT)

\begin{tabular}{|c|c|}
\hline Statistik & Nilai \\
\hline Maksimum & 29 \\
\hline Minimum & 19 \\
\hline $\bar{X}$ & 24,88 \\
\hline $\mathrm{S}^{2}$ & 6,09 \\
\hline $\mathrm{S}$ & 2,47 \\
\hline
\end{tabular}

Sumber :Hasil Perhitungan dari Data Hasil Penelitian Untuk mendeskripsikan hasil tes kognitif siswa yang pembelajarannya menggunakan model pembelajaran kooperatif tipe Numbered Heads Together (kelas X-2), maka ditentukan kriterianya sesuai dengan ketentuan berikut :

$$
\begin{aligned}
& 19+4(2)=27 \\
& 19+3(2)=25 \\
& 19+2(2)=23 \\
& 19+1(2)=22
\end{aligned}
$$

\begin{tabular}{|c|c|c|c|}
\hline $\begin{array}{c}\text { Rentang } \\
\text { Skor }\end{array}$ & $\begin{array}{c}\text { Harg } \\
\text { a }\end{array}$ & $\begin{array}{c}\text { Rentang } \\
\text { Skor }\end{array}$ & Kategori \\
\hline $\begin{array}{l}\text { Skor Min }+4 \\
\text { (Std Deviasi) }\end{array}$ & 27 & $\geq 27$ & $\begin{array}{l}\text { Sangat } \\
\text { baik }\end{array}$ \\
\hline $\begin{array}{l}\text { Skor Min }+3 \\
(\text { Std Deviasi) }\end{array}$ & 25 & $\geq 25<27$ & Baik \\
\hline $\begin{array}{l}\text { Skor Min }+2 \\
(\text { Std Deviasi) }\end{array}$ & 23 & $\geq 23<25$ & Cukup \\
\hline \multirow[t]{2}{*}{$\begin{array}{l}\text { Skor Min }+1 \\
(\text { Std Deviasi) }\end{array}$} & 22 & $\geq 22<23$ & Rendah \\
\hline & & $<22$ & $\begin{array}{l}\text { Sangat } \\
\text { Rendah }\end{array}$ \\
\hline
\end{tabular}

Kriteria Hasil Kognitif Siswa Kelas X-2

Sumber : Hasil Pengolahan Data 
d. Hasil Belajar Kognitif Siswa dengan Menggunakan Model Pembelajaran Kooperatif tipe Teams Game Tournament (TGT.

Berdasarkan tes hasil belajar pada konsep Etika Lingkungan yang telah dilakukan terhadap siswa kelas X-6 SMA Negeri 5 Tasikmalaya, sebanyak 30 soal dengan rentang skor 0 sampai 30 diperoleh hasil sebagai berikut :

Data Statistik Hasil Belajar Kognitif Siswa Menggunakan

Model Pembelajaran Kooperatif Tipe Teams Game Tournament (TGT).

\begin{tabular}{|c|c|}
\hline Statistik & Nilai \\
\hline Maksimum & 28 \\
\hline Minimum & 18 \\
\hline $\bar{X}$ & 22,98 \\
\hline $\mathrm{S}^{2}$ & 5,30 \\
\hline $\mathrm{S}$ & 2,30 \\
\hline
\end{tabular}

Sumber :Hasil Perhitungan dari data hasil penelitian

Untuk mendeskripsikan hasil tes kognitif siswa yang pembelajarannya menggunakan model pembelajaran kooperatif tipe Teams Game Tournament (kelas X-6), maka ditentukan kriterianya sesuai dengan ketentuan berikut :

$$
\begin{aligned}
& 18+4(2)=26 \\
& 18+3(2)=24 \\
& 18+2(2)=22 \\
& 18+1(2)=21
\end{aligned}
$$

Tabel

Kriteria Hasil Kognitif Siswa

Kelas X-6

\begin{tabular}{|c|c|c|c|}
\hline $\begin{array}{c}\text { Rentang } \\
\text { Skor }\end{array}$ & $\begin{array}{c}\text { Harg } \\
\text { a }\end{array}$ & $\begin{array}{c}\text { Rentan } \\
\text { g Skor }\end{array}$ & $\begin{array}{c}\text { Katego } \\
\text { ri }\end{array}$ \\
\hline $\begin{array}{c}\text { Skor Min + 4 } \\
\text { (Std Deviasi) }\end{array}$ & 26 & $\geq 26$ & $\begin{array}{c}\text { Sangat } \\
\text { baik }\end{array}$ \\
\hline $\begin{array}{c}\text { Skor Min + 3 } \\
\text { (Std Deviasi) }\end{array}$ & 24 & $\geq 24$ & Baik \\
\hline $\begin{array}{c}\text { Skor Min + 2 } \\
\text { (Std Deviasi) }\end{array}$ & 22 & $\geq 22<24$ & Cukup \\
\hline $\begin{array}{c}\text { Skor Min + 1 } \\
\text { (Std Deviasi) }\end{array}$ & 21 & $\geq 21<22$ & Rendah \\
\hline & & $<21$ & $\begin{array}{c}\text { Sangat } \\
\text { Rendah }\end{array}$ \\
\hline
\end{tabular}

Sumber : hasil pengolahan data

\section{Pengujian Hipotesis}

\section{Perbedaan Keaktifan Belajar Siswa}

Untuk mengetahui perbedaan keaktifan belajar siswa pada materi konsep etika lingkungan, antara siswa yang pembelajarannya menggunakan model pembelajaran kooperatif tipe Numbered Heads Together ( NHT) pada kelas X-2 dengan Teams Game Tournament (TGT) pada kelas X-6, dilakukan observasi dengan 4 aspek penilaian yaitu keseriusan, mengemukakan gagasan, bertanya/menjawab, dan disiplin, dimana hasil observasi tersebut telah dilakukan uji prasyarat analisis dengan hasil bahwa kedua data tersebut berdistribusi normal dan homogen. Dengan demikian uji yang akan digunakan untuk megetahui perbedaan keaktifan belajar siswa dengan uji t.

Kaidah pengujian hipotesis yang digunakan adalah

Hipotesis statistik yang akan diuji adalah : 
Ho $: \mu_{\mathrm{A}}=\mu_{\mathrm{B}}:$ Tidak terdapat perbedaan rata-rata antara kedua kelompok data.

$\mathrm{H}_{1}: \mu_{\mathrm{A}} \neq \mu_{\mathrm{B}}:$ Terdapat perbedaan rata-rata antara kedua kelompok data.

Kaidah pengujian hipotesis yang digunakan adalah: terima Ho jika $-\mathbf{t}_{\text {tabel }}<\mathbf{t}_{\text {hitung }}<+\mathbf{t}$ tabel

Hasil analisis dapat dilihat pada tabel berikut.

Tabel

Ringkasan Hasil Uji t

\begin{tabular}{|c|c|c|c|}
\hline thitung & $\mathbf{t}_{\text {tabel }}$ & Hasil Analisis & $\begin{array}{c}\text { Kesimpulan } \\
\text { Analisis }\end{array}$ \\
\hline$-7,29$ & 1,99 & $\begin{array}{c}\mathrm{t}_{\text {hitung }} \text { berada di } \\
\text { luar interval } \\
\text { - }\end{array}$ & Tolak Ho \\
& & $\begin{array}{c}\text { thitung } \\
\mathrm{t}_{\text {hitung }}\end{array}$ & \\
\hline
\end{tabular}

Sumber : Hasil Perhitungan uji t

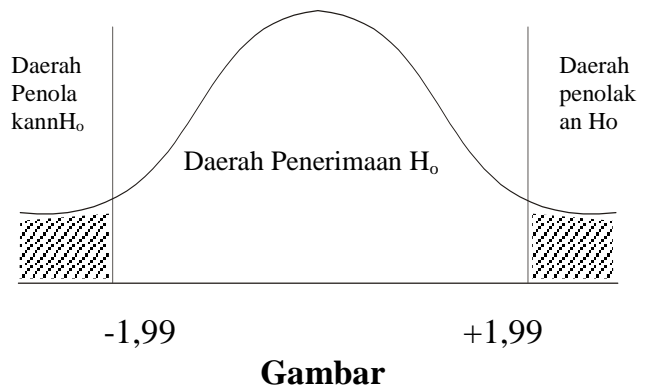

Grafik Perbandingan $\mathbf{t}_{\text {hitung }}$ dengan $\mathbf{t}_{\text {tabel }}$ Dengan demikian, hipotesis yang penulis ajukan yaitu, terdapat perbedaan keaktifan belajar siswa kelas $\mathrm{X}$ SMA Negeri 5 Tasikmalaya semester kedua pada konsep Etika Lingkungan yang menggunakan model pembelajaran kooperatif tipe Numbered Heads Together(NHT) bisa diterima.

Hasil belajar dengan model pembelajaran kooperatif tipe Numbered Heads Together (NHT) nilai rata-ratanya 11,74 lebih tinggi dari pada hasil belajar yang menggunakan model pembelajaran kooperatif tipe Teams Game Tournament (TGT) dengan nilai rata-rata 11,64 sehingga model pembelajaran kooperatif tipe Numbered Heads Together (NHT) memiliki keaktifan belajar yang lebih baik.

\section{Perbedaan Hasil Belajar Kognitif Siswa}

Untuk

mengetahui perbedaan hasil belajar kognitif siswa pada konsep etika lingkungan antara siswa yang proses pembelajaranya menggunakan model pembelajaran kooperatif tipe Numbered Heads Together (NHT) dengan Teams Games Tournament (TGT), berdasarkan hasil pengujian persyarat ananalisis bahwa data hasil tes belajar siswa kedua kelompok berasal dari populasi yang berdistribusi normal dan kedua data mempunyai varians yang homogen, maka pengujian dilanjutkan dengan menggunakan uji t.

Hipotesis statistik yang akan diuji adalah :

Ho : $\mu_{\mathrm{A}}=\mu_{\mathrm{B}}$ : Tidak terdapat perbedaan rata-rata antara kedua kelompok data.

$\mathrm{H}_{1}: \mu_{\mathrm{A}} \neq \mu_{\mathrm{B}}$ : Terdapat perbedaan rata-rata antara kedua kelompok data.

Kaidah pengujian hipotesis yang digunakan adalah: terima Ho jika $-t_{\text {tabel }}<t$ hitung $<+t$ tabel

Hasil analisis dapat dilihat pada tabel berikut: 


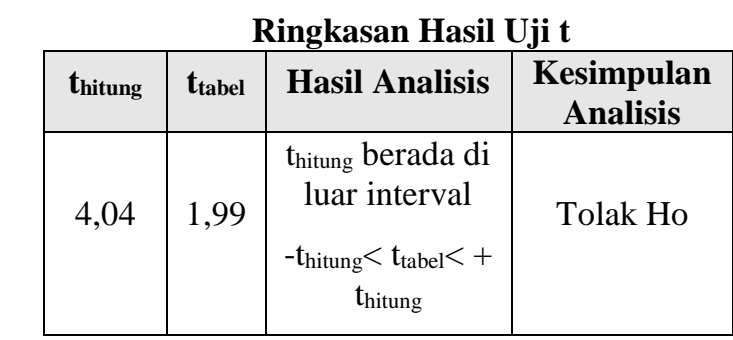

Sumber : Hasil Perhitungan uji t

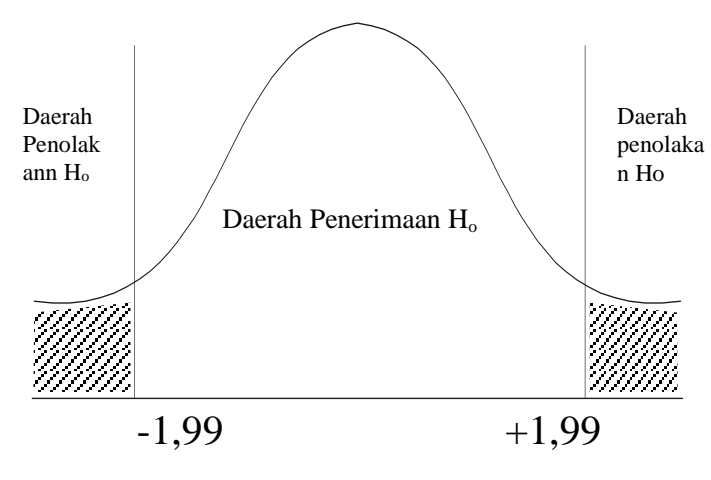

Gambar

Grafik Perbandingan $t_{\text {hitung }}$ dengan $\mathbf{t}_{\text {tabel }}$

Dengan demikian, hipotesis yang penulis ajukan yaitu, terdapat perbedaan hasil belajar siswa kelas X SMA Negeri 5 Tasikmalaya semester kedua pada konsep Etika Lingkungan yang menggunakan model pembelajaran kooperatif tipe Numbered Heads Together (NHT) bisa diterima.

Hasil belajar dengan model pembelajaran kooperatif tipe Numbered Heads Together (NHT) nilai rata-ratanya 24,88 lebih tinggi dari pada hasil belajar yang menggunakan model pembelajaran kooperatif tipe Teams Game Tournament (TGT) dengan nilai rata-rata 22,98 sehingga model pembelajaran kooperatif tipe Numbered Heads Together (NHT) memiliki hasil belajar yang lebih baik

\section{PENUTUP}

\section{Simpulan}

1. Terdapat perbedaan keaktifan belajar siswa antara yang menggunakan model pembelajaran kooperatif tipe Numbered Heads Together (NHT) yang di terapkan pada kelas X-2 dengan Teams Game Tournament (TGT) yang diterapkan di kelas X6 pada konsep Etika Lingkungan. Hal ini berdasarkan hasil observasi yang menunjukan bahwa skor ratarata keaktifan siswa kelas X-2 yang menggunakan model pembelajaran kooperatif tipe Numbered Heads Together (NHT) memperoleh rata-rata sebesar 11.74 yang lebih baik di bandingkan dengan siswa kelas $\mathrm{X}$ 6 yang menggunakan model pembelajaran kooperatif tipe Teams Game Tournament (TGT) yang memperoleh nilai rata-rata sebesar 11,64.

2. Terdapat perbedaan hasil belajar kognitif siswa antara yang menggunakan model pembelajaran kooperatif tipe Numbered Heads Together (NHT) yang di terapkan pada kelas X-2 dengan Teams Game Tournament (TGT) yang diterapkan di kelas X6 pada konsep Etika Lingkungan. Hal ini berdasarkan hasil tes kognitif yang menunjukan bahwa skor rata-rata keaktifan siswa kelas $\mathrm{X}-2$ yang menggunakan model pembelajaran kooperatif tipe Numbered Heads Together (NHT) memperoleh nilai rata-rata sebesar 24,88 yang lebih baik di bandingkan dengan siswa kelas X6 yang menggunakan model pembelajaran kooperatif tipe Teams Game Tournament (TGT) 
yang memperoleh nilai rata-rata sebesar 22,98 sehingga model pembelajaran kooperatif tipe Numbered Heads Together (NHT) memiliki hasil belajar kognitif lebih baik.

3. Model pembelajaran kooperatif tipe Numbered Heads Together (NHT) lebih baik digunakan dalam keaktifan belajar siswa di bandingkan dengan model pembelajaran kooperatif tipe Teams Game Tournament (TGT) .Hal ini berdasarkan hasil observasi yang menunjukan bahwa skor rata-rata keaktifan siswa kelas X-2 yang menggunakan model pembelajaran kooperatif tipe Numbered Heads Together (NHT) memperoleh rata-rata sebesar 11.74 yang lebih baik di bandingkan dengan siswa kelas X6 yang menggunakan model pembelajaran kooperatif tipe Teams Game Tournament (TGT) yang memperoleh nilai rata-rata sebesar 11,64.

4. Model pembelajaran kooperatif tipe Numbered Heads Together (NHT) lebih baik digunakan dalam hasil belajar kognitif di bandingkan dengan model pembelajaran kooperatif tipe Teams Game Tournament (TGT) .Hal ini berdasarkan hasil tes kognitif yang menunjukan bahwa skor rata-rata keaktifan siswa kelas $\mathrm{X}-2$ yang menggunakan model pembelajaran kooperatif tipe Numbered Heads Together (NHT) memperoleh nilai rata-rata sebesar 24,88 yang lebih baik di bandingkan dengan siswa kelas X6 yang menggunakan model pembelajaran kooperatif tipe Teams Game Tournament (TGT) yang memperoleh nilai rata-rata sebesar 22,98 sehingga model pembelajaran kooperatif tipe Numbered Heads Together (NHT) memiliki hasil belajar kognitif lebih baik.

\section{DAFTAR PUSTAKA}

Arikunto, Suharsimi. 2006.

Prosedural Penelitian Suatu Pendekatan Praktek. Edisi Revisi V. Bandung : Bumi Aksara.

Dimyati dan Mujiono 2006. Belajar dan Pembelajaran. Jakarta: Rienika Cipta.

Hamalik Oemar. 2009.

Proses Belajar Mengajar.

Jakarta : Bumi Aksara.

Lie. Anita. 2008. Cooperative

Learning. Jakarta : Grasindo

Slavin, 2010. Cooperative

Learning. Jakarta :

Slameto. 2010. Belajar dan

Faktor-faktor yang mempengaruhinya. Jakarta. Asdi Mahasatya

Suprijono, Agus. 2010.

Cooperative Learning.

Yogyakarta: Pustaka Pelajar 